\title{
Applying the Service-Profit Chain to Internet Service Businesses
}

\author{
Jin-Woo Kim,", Michael Richarme ${ }^{1,2, \#}$ \\ ${ }^{1}$ Department of Marketing, College of Business, The University of Texas at Arlington, Arlington, Texas, USA; ${ }^{2}$ Decision Analyst, \\ Arlington, Texas, USA. \\ Email: ${ }^{*}$ jkim@uta.edu, ${ }^{*}$ richarme@uta.edu
}

Received March $2^{\text {nd }}, 2009$; revised April $7^{\text {th }}, 2009$; accepted April $28^{\text {th }}, 2009$.

\begin{abstract}
Service-profit chain (SPC) is a powerful tool for evaluating the relationship between the degree of service effort and profit. This framework has been empirically tested in the banking, hospital, retail, and other brick and mortar service verticals. This paper extends the applicability of SPC to Internet-based businesses. The paper also investigates the moderating roles of customer satisfaction and advertising spending on the service operation efficiency (SOE) and profit relationship. Analysis of U.S. Internet service providers during a seven year period from 2000 to 2006 indicates that service operations efficiency is positively associated with a firm's profit. However, the customer satisfaction and advertising spending constructs are negative moderators of the relationship between service operations efficiency and profit.
\end{abstract}

Keywords: service-profit chain, service operations efficiency, customer satisfaction, data envelopment analysis

\section{Introduction}

Service-profit chain (SPC) is a useful framework in explaining the relationship between service operation and a firm's profit. From the SPC literature, a service firm's profit can be improved by effective service operational input through customer perception and actual behavior [1]. SPC has been empirically tested with bank service $[2,3,4]$, retail chain [5], and business market [6] verticals. SPC can provide a useful integrated foundation for measuring service improvement effort as it relates to ultimate management goals.

Given that prior empirical testing of this framework has focused on brick and mortar services, there is an opportunity to extend the framework to Internet-based businesses. Moreover, the moderating roles of customer satisfaction and advertising spending have not been fully addressed in the SPC model. Prior research in the field of SPC omits the roles of strategic levers such as customer satisfaction and advertising expenditures in transferring service improvement effort to profitability. Little attention has been paid to how customer satisfaction and advertising expenditures moderate the relationship between the degree of service effort and the firm's profit. Motivated by this research gap, the study investigates these moderating variables using U.S. Internet service business data.
For this paper, a research framework is developed based on extant theory. Next, a methodology description section addresses the research setting and data available for the analysis. U.S. Internet service business data regarding service operations efficiency, customer satisfaction, advertising spending and real profit are utilized. For this analysis, Data Envelopment Analysis (DEA) is utilized to determine the service operations efficiency by integrating the operations input and outcome. Then, regression analysis is conducted to shows that Internet service operations efficiency is related to real profit. In the analysis and discussion section, the results are interpreted and some theoretical and managerial insights are presented.

\section{Research Framework}

As mentioned earlier, prior research tends to focus on the service quality assessment of individual consumers using traditional brick and mortar retail and banking services. In this study, Internet service operations efficiency is considered as an independent variable and profit as the dependent variable. Two possible moderators, customer satisfaction and advertising expenditures, are added to the SPC framework as shown in Figure 1. 


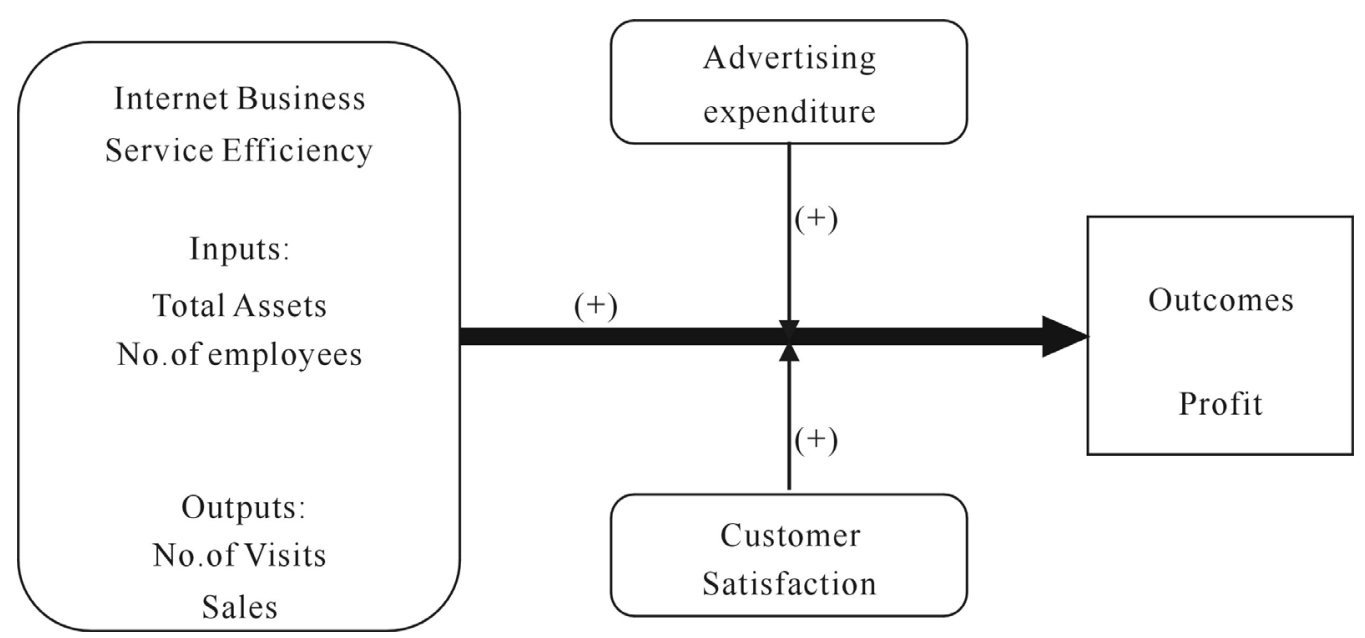

Figure 1. Research framework

\subsection{Impact of Service Operations Efficiency on Firm's Profit}

Service operations efficiency is expected to lead to an increase in a firm's profit. There is often a time lag for this relationship to become evident [7]. Linking the constructs of service operations, employee assessments and customer assessments to profit was proposed from the empirical evidence derived from 20 large service organizations [1]. A modified version of the service profit chain was employed to take into account the employee and customer assessments relationship to profit [8].

Loveman and Heskett (2008) updated the SPC model by adopting employee capability and external service quality. Basically, there are four principal components of the service profit chain: internal service quality, external service quality and service value, target market of customers, and financial performance [9]. In the same manner, the SPC framework can be applied to Internet businesses.

\subsection{The Moderating Role of Customer Satisfaction}

SPC is a valuable framework that offers insights to make it possible observe service related issues in an integrative perspective [4]. The comprehensive SPC framework models processes and constructs between service quality and profit, indicating that operating strategy and service delivery system could lead to employee satisfaction, customer satisfaction and customer loyalty [9]. In prior research, customer satisfaction is expected to moderate the relationship between corporate social responsibility and market value. This result can be attributed to customer satisfaction, which makes it possible to convert corporate social responsibility to financial value [10].

In this sense, service improvement effort will have an impact on profit after it interacts with customer satisfac- tion. When a firm with high customer satisfaction employs a strategy to improve service quality, net income will increase. If consumer does not notice the service effort, changes in profit will be stable or only marginally improved. However, if the customer recognizes the increased SOE, the firm can realize the more profit. Therefore, customer satisfaction will play a moderating role between service quality effort and firm's profit. Service improvement effort without customer recognition of the improvement will not be effective.

\subsection{The Moderating Role of Advertising Expen- ditures}

Advertising has often been treated as an input variable of marketing credibility and advertising efficiency $[11,12$, $13,14]$. In this expanded SPC model, advertising expenditures will be examined as a moderator of the relationship between service efforts and profit. Information on service improvement can be delivered to customers by advertising and other promotion activities. Therefore, advertising expenditures are expected to positively moderate the relationship between service effort and profit.

This proposition is based on advertising effects over times. Even though advertising effects will increase to an initial peak but decrease due to time passage, advertising amount and cost will be a moderating effect regardless of this factor. All the advertising does not have a positive impact on customer satisfaction and profit. Advertising will increase customer awareness of the level of service effort generated by the firm, and ultimately, the level of the firm's profit [15].

\section{Research Setting and Data Description}

The analysis for this application consists of two steps as seen in the Figure 2. Multiple input and outputs are se- 
lected to represent the service operations efficiency construct. After defining these inputs and outputs, SOE is estimated using Data Envelopment Analysis (DEA). This technique is one of the most popular management science tools used to determine a firm's efficiency level from multiple inputs and multiple outputs. A quick background of the DEA technique is provided in the Appendix. From this first step, the SOE estimates will be the regressor and the firm's profit will be the response in the regression equations.

\subsection{Measuring Service Operations Efficiency}

The concept of service operations efficiency can be a very useful indicator that focuses on "Do things in the right manner" rather than "Do the right things." Since the early 1990's, many researchers have started to study service quality and assessment from a macro-economic point of view. The DEA technique has become a useful management science tool, in which multiple inputs and multiple outputs can be involved simultaneously, whereas regression cannot include multiple responses [16]. In particular, DEA is a tool for evaluating marketing's credibility [13], retail productivity $[17,18]$, sales force performance $[19,20]$, and advertising efficiency $[11,12,14]$. Also, DEA is used to compute efficiency of supply chain processes $[21,22]$ and operations efficiency [23].

The efficiency of one $\mathrm{DMU}_{1}$ can be obtained as a solution to maximize its efficiency subject to the efficiency of all DMUs being less than or equal to 1 . The solution produces the weights which are most favorable to the $\mathrm{DMU}_{1}$ and provides a measure of efficiency for that $\mathrm{DMU}_{1}$. The solution produces the weights which are most favorable to the $\mathrm{DMU}_{1}$ and provides a measure of efficiency for the $\mathrm{DMU}_{1}$. The algebraic model is as follows:

$$
\begin{gathered}
\text { Max } h_{0}=\frac{\sum_{r} \text { weight }_{r} \text { Output }_{r} D M U_{1}}{\sum_{i} \text { weight }_{i} \text { Input }_{i} D M U_{1}} \\
\text { subject to } \\
\frac{\sum_{r} \text { weight }_{r} \text { Output }_{r} \text { DMU }_{j}}{\sum_{i} \text { weight }_{i} \text { Input }_{i} \text { DMU }_{j}} \leq 1 \text { for each } \mathrm{DMU}_{\mathrm{j}},
\end{gathered}
$$$$
\text { weight }_{r}, \text { weight }_{i} \geq \varepsilon
$$

Several studies have examined efficiency measures of on-line businesses by using the DEA methodology. The efficiency of service delivery processes was computed based on a survey of 135 large U.S. retail banks holding more than $75 \%$ of the total assets in the industry in 1994. Activity time (minutes), technology, and functionality were regarded as multiple inputs and check cycle time (day), ATM cycle time (day), and customer time (minutes) were considered as multiple outputs [24].

The efficiency of several search engines was investigated by using a query search as a production process and compared to each other by employing a simple data envelopment analysis model. The seven primary search engines utilized were Alta Vista, Excite, Lycos, Infoseek, Open Text, Hotbed, and Web Crawler. Intermediate inputs included the number of pages, update freshness, time for data retrieval, and feature on fourteen information retrieval items. Output variables included precision and circulation. A survey conducted by Internet media companies provided fifteen queries that are submitted to each engine and then the first twenty returned results were considered in calculating the values [25].

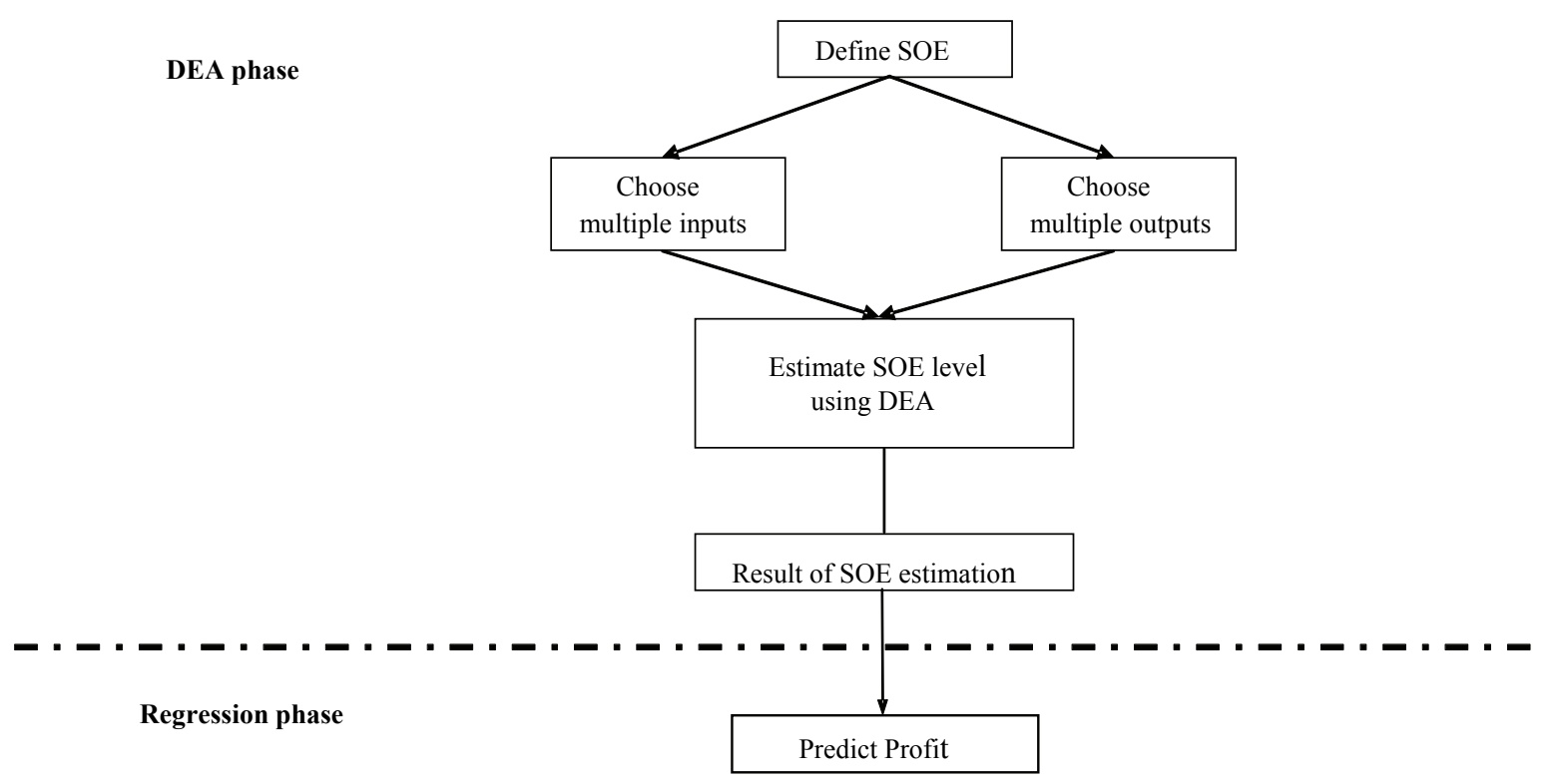

Figure 2. Research process 
The concept of 'customer efficiency' was established and linked to e-business management practices. For this purpose, purchase activity time and non-purchase activity time were used as multiple inputs and number of informational transactions, number of service transactions, and number of purchases were considered as multiple outputs for computation of the efficiency construct [26].

Given this, service operations efficiency is measured with two inputs and two outputs in this study. From Resource Based View (RBV) theory, total assets and number of employees are considered as inputs. Multiple outputs include total number of visit and total sales. Suppose that the Amazon's total asset and number of employees are 5 and 6 , and total number of site visits and total sales are 7 and 8 while eBay's input values are 5 and 8 , and output values are 3 and 4 . The efficiency of Amazon $\left(h_{0}\right)$ can be obtained by solving the following model:

$$
\operatorname{Max} h_{0}=\frac{\text { weight }_{\text {asset }} 7+\text { weight }_{\text {employee }} 8}{\text { weight }_{\text {visit }} 5+\text { weight }_{\text {sales }} 6}
$$

subject to

$$
\begin{aligned}
& \frac{\text { weight }_{\text {asset }} 7+\text { weight }_{\text {employee }} 8}{\text { weight }_{\text {visit }} 5+\text { weight }_{\text {sales }} 6} \leq 1 \quad \text { (Amazon), } \\
& \frac{\text { weight }_{\text {asset }} 3+\text { weight }_{\text {employee }} 4}{\text { weight }_{\text {visit }} 5+\text { weight }_{\text {sales }} 8} \leq 1 \quad \text { (eBay), } \\
& \ldots \ldots \ldots \ldots \text { for remaining DMUs } \\
& \text { and } \\
& \text { weight }_{\text {asset }} \text {, weight }
\end{aligned}
$$

If $h_{0}$ is equal to 1 then Amazon is efficient relative to other DMUs but if $h_{0}$ is less than 1, some other DMU is more efficient than Amazon.

\subsection{Predicting Firm's Profit}

After SOE is computed, several multivariate regression analyses were conducted to grasp the effects of SOE and other factors on firm's profit as the following:

$$
\begin{aligned}
& \text { Model } 1 \text { Profit }_{t}=a+b 1 S O E_{t}+b 2 A D_{t}+b 3 C S_{t} \\
& \text { Model } 2 \text { Profit }_{t}=a+b 1 S O E_{t}+b 2 A D_{t}+b 3 C S_{t} \\
& +b 4 \text { ASSET }_{t}+b 5 \text { SALES }_{t} \\
& +b 6 E M P L_{t}+b 7 S O E_{t}^{*} A D_{t} \\
& +b 8 \mathrm{SOE}_{t}^{*} C S_{t} \\
& \text { Model } 3 \text { Profit }_{t}=a+b 1 \text { SOE }_{t}+b 2 \text { ASSET }_{t} \\
& +b 3 S_{A L E S_{t}}+b 4 E M P L_{t} \\
& +b 5 S_{O} E_{t}^{*} A D_{t}+b 6 S O E t^{*} C S_{t} \\
& +b 7 \text { YEAR_1+b8 YEAR_2 }
\end{aligned}
$$

$$
\begin{aligned}
& \text { + b9 YEAR_3 + b10YEAR_4 } \\
& +b 11 \text { YEAR_5 + b12 YEAR_6 } \\
& + \text { b13 INDUSTRY_1 } \\
& \text { + b14 INDUSTRY } 2 \\
& \text { + b15 INDUSTRY } 3 \\
& \text { Model } 4 \text { Profit }_{t}=a+b 1 S O E_{t}+b 2 A D_{t}+b 3 C S_{t} \\
& +b 4 \text { ASSET }_{t}+b 5 \text { SALES }_{t} \\
& +b 6 E M P L_{t}+b 7 S O E_{t}^{*} A D_{t} \\
& +b 8 S O E_{t}{ }^{*} C S_{t}+b 9 \text { YEAR_1 } \\
& +b 10 \text { YEAR_2+b11YEAR_3 } \\
& \text { + b12 YEAR_4+b13 YEAR_5 } \\
& + \text { b14 YEAR_6 } \\
& \text { + b15 INDUSTRY_1 } \\
& \text { + b16 INDUSTRY_2 } \\
& \text { + b17 INDUSTRY } 3
\end{aligned}
$$

One year-lagged impact of SOE on profit was analyzed using multivariate regression as following:

$$
\begin{aligned}
& \text { Model } 5 \text { Profit }_{t+1}=a+b 1 S O E_{t}+b 2 A D_{t}+b 3 C S_{t} \\
& \text { Model } 6 \text { Profit }_{t+1}=a+b 1 S O E_{t}+b 2 A D_{t}+b 3 C S_{t} \\
& +b 4 A_{S S E T_{t}}+b 5 S A L E S_{t} \\
& +b 6 E M P L_{t}+b 7 S O E_{t} * A D_{t} \\
& +b 8 \mathrm{SOE}_{t} * C S_{t} \\
& \text { Model } 7 \text { Profit }_{t+1}=a+b 1 S O E_{t}+b 2 A D_{t} \\
& +b 3 C S_{t}+b 4 A_{S S E T} \\
& +b 5 S A L E S_{t}+b 6 E M P L_{t} \\
& +b 7 S_{S O E_{t}} * A D_{t}+b 8 S O E_{t} * C S_{t} \\
& +b 9 \text { YEAR_1 + b10YEAR_2 } \\
& \text { + b11 YEAR_3+b12 YEAR_4 } \\
& \text { + b13 YEAR_5 + b14 YEAR_6 } \\
& + \text { b15 INDUSTRY_1 } \\
& \text { + b16 INDUSTRY } 2 \\
& \text { + b17 INDUSTRY } 3
\end{aligned}
$$

\subsection{Data Description}

This study obtains data on total assets, total number of employees, total number of visits to web sites, total sales, customer satisfaction levels, advertising expenditure sand profitability for 70 observations of U.S. Internet-based business firms. For example, Amazon, Yahoo, Travelocity and NewYorkTimes.com are included to represent retail, portal, travel and news service firms, respectively. The data are obtained from various secondary sources. The multiple inputs and outputs chosen in this study are shown in Table 1.

For computation of SOE, total annual assets and total 
Table 1. Measures and operationalization

\begin{tabular}{|c|c|c|c|}
\hline Variable & Measure & Operationalization & Data Source \\
\hline Independent variable & SOE & Service operations efficiency & Calculated by DEA \\
\hline \multirow{2}{*}{ DEA Inputs } & ASSET & Annual total assets $\quad(10$ Thousand dollars) & $\begin{array}{l}\text { COMPUSTAT North America } \\
\text { (http://wrds.wharton.upenn.edu/ds/comp/inda/) }\end{array}$ \\
\hline & EMPL & Total number of employee (persons) & COMPUSTAT North America \\
\hline \multirow{2}{*}{ DEA Outputs } & VISIT & Total number of visit to web site & $\begin{array}{l}\text { MediaMetrix:ComScore } \\
\text { (http://www.comscore.com) }\end{array}$ \\
\hline & SALES & Annual total sales (10 Thousand dollars) & COMPUSTAT North America \\
\hline \multirow{2}{*}{ Moderator } & $\mathrm{AD}$ & Advertising expenditure (10 Thousand dollars) & COMPUSTAT North America \\
\hline & $\mathrm{CS}$ & Customer satisfaction score & ACSI (http://www.theacsi.org/index) \\
\hline Dependent Variable & PROFIT & Annual Profit (10 Thousand dollars) & COMPUSTAT North America \\
\hline \multirow{2}{*}{ Control Variables } & YEAR & Six annual dummies & $2000 \sim 2006$ \\
\hline & INDUSTRY & Three industry dummies & News, Portal, Travel, Retail \\
\hline
\end{tabular}

number of employees are considered as DEA inputs and total sales and total number of web visit are taken into account as DEA outputs. Total number of web visits, one of the DEA outputs, utilizes MediaMetrix ComScore results for the Top $50 \mathrm{Web}$ and Digital Media Properties. A customer satisfaction score is provided by the American Customer Satisfaction Index. To capture the effect of year and industry types, six and three dummy variables are utilized by the regression equation, respectively. The data were examined for completeness and outliers. After data cleansing, data from 2000 to 2006 were merged to provide the final dataset with 70 observations.

\section{Analysis \& Discussion}

The service operations efficiency variable is computed by DEA, and then a regression procedure is conducted to test the main effect of service operations efficiency on profit and the moderating effects of customer satisfaction and advertising expenditures on the service-profit chain. Table 2 displays the correlation matrix between variables and shows that some variables are positively or negatively related to each other.

\subsection{Results of SOE}

Unlike regression, DEA does not impose any particular functional form on the data, creating a more flexible piecewise linear function. Also, unlike total factor productivity indexes, DEA gives each of the observations its own set of weights. This efficient frontier line provides a more realistic benchmark because the decision-making units (DMUs) are compared to best practices rather than to average performance $[27,28]$.

Table 2. Correlation matrix

\begin{tabular}{|c|c|c|c|c|c|c|c|c|}
\hline & SOE & $\mathrm{CS}$ & ASSET & SALES & PROFIT & EMPL & $\mathrm{AD}$ & VISIT \\
\hline SOE & 1 & & & & & & & \\
\hline $\mathrm{CS}$ & .375 & 1 & & & & & & \\
\hline ASSET & -.351 & -.362 & 1 & & & & & \\
\hline SALES & -.352 & -.311 & .953 & 1 & & & & \\
\hline PROFIT & -.275 & -.331 & .901 & .915 & 1 & & & \\
\hline EMPL & -.485 & -.401 & .749 & .829 & .600 & 1 & & \\
\hline $\mathrm{AD}$ & -.413 & -.408 & .879 & .824 & .644 & .833 & 1 & \\
\hline VISIT & .123 & .046 & .526 & .490 & .594 & .112 & .312 & 1 \\
\hline
\end{tabular}


Table 3. Input oriented SOE

\begin{tabular}{|c|c|c|c|}
\hline DMU Name & Input-Oriented Efficiency & DMU Name & Input-Oriented Efficiency \\
\hline 2000 Amazon.com & 0.21098 & 2003 NYTimes.com & 0.13394 \\
\hline 2000 barnesandnoble.com & 0.19039 & 2003 Orbitz Worldwide & 1.00000 \\
\hline 2000 eBay & 0.21376 & 2003 Yahoo & 0.50792 \\
\hline 2000 Ask.com & 0.06937 & 2004 Amazon.com & 0.33998 \\
\hline 2000 Microsoft & 0.17061 & 2004 ABCNEWS.com & 0.09009 \\
\hline 2000 priceline.com & 1.00000 & 2004 eBay & 0.23426 \\
\hline 2000 CNN.com & 0.13340 & 2004 Expedia & 0.16024 \\
\hline 2000 Travelocity.com & 0.32821 & 2004 USATODAY.com & 0.07569 \\
\hline 2000 Yahoo! Inc. & 0.42136 & 2004 Google & 0.66749 \\
\hline 2001 Amazon.com & 0.34563 & 2004 Ask.com & 0.06921 \\
\hline 2001 ABCNEWS.com & 0.09131 & 2004 Microsoft News & 0.18779 \\
\hline 2001 eBay & 0.26161 & 2004 CNN.com & 0.14406 \\
\hline 2001 USATODAY.com & 0.07650 & 2004 Yahoo & 0.41334 \\
\hline 2001 Ask.com & 0.08376 & 2005 Amazon.com & 0.36273 \\
\hline 2001 Microsoft News & 0.15443 & 2005 ABCNEWS.com & 0.09489 \\
\hline 2001 NYTimes.com & 0.13850 & 2005 eBay & 0.18532 \\
\hline 2001 Travelocity.com & 0.43571 & 2005 Expedia & 0.15167 \\
\hline 2001 Yahoo! Inc. & 0.56876 & 2005 USATODAY.com & 0.07622 \\
\hline 2002 Amazon.com & 0.35086 & 2005 Google & 0.52688 \\
\hline 2002 barnesandnoble.com & 0.75451 & 2005 Ask.com & 0.07423 \\
\hline 2002 ABCNEWS.com & 0.07992 & 2005 Microsoft News & 0.18954 \\
\hline 2002 eBay & 0.23832 & 2005 NYTimes.com & 0.15993 \\
\hline 2002 Expedia & 0.26294 & 2005 CNN.com & 0.14439 \\
\hline 2002 USATODAY.com & 0.07385 & 2005 Yahoo & 0.37270 \\
\hline 2002 Ask.com & 0.05788 & 2006 Amazon.com & 0.38766 \\
\hline 2002 Microsoft News & 0.16322 & 2006 ABCNEWS.com & 0.09023 \\
\hline 2002 NYTimes.com & 0.13380 & 2006 eBay & 0.21310 \\
\hline 2002 Yahoo & 0.59576 & 2006 Expedia & 0.13320 \\
\hline 2003 Amazon.com & 0.43322 & 2006 USATODAY.com & 0.07819 \\
\hline 2003 ABCNEWS.com & 0.08548 & 2006 Google & 0.39674 \\
\hline 2003 eBay. & 0.30988 & 2006 Ask.com & 0.11476 \\
\hline 2003 USATODAY.com & 0.07206 & 2006 Microsoft News & 0.18124 \\
\hline 2003 Google & 1.00000 & 2006 NYTimes.com & 0.21718 \\
\hline 2003 Ask.com & 0.07155 & 2006 CNN.com & 0.13863 \\
\hline 2003 Microsoft News & 0.17006 & 2006 Yahoo & 0.34974 \\
\hline
\end{tabular}

The DEA results were computed by DEA Excel Solver to obtain overall efficiency scores for U.S. Internet service providers from 2000 to 2006. DEA analysis provides the service operations efficiency for all compa- nies based on each company's combination of inputs and outputs compared to those of others in the sample. For calculation of the overall SOE of each company, seven years data are combined as one dataset. Given this, the 
Table 4. Regression result (DV=Profit $\left.{ }_{t}\right)$

\begin{tabular}{|c|c|c|c|c|c|c|c|c|}
\hline & \multicolumn{2}{|c|}{ Model 1} & \multicolumn{2}{|c|}{ Model 2} & \multicolumn{2}{|c|}{ Model 3} & \multicolumn{2}{|c|}{ Model 4} \\
\hline & Beta & P-value & Beta & P-value & Beta & P-value & Beta & P-value \\
\hline (Constant) & 19.703 & .041 & 1.685 & 0.763 & 0.418 & 0.414 & 2.316 & 0.71 \\
\hline SOE & -.143 & .965 & 37.149 & 0.092 & 29.509 & $0.05^{*}$ & 24.707 & 0.25 \\
\hline SOE*CS & & & -4.216 & 0.101 & -3.44 & 0.046 & -2.867 & 0.256 \\
\hline $\mathrm{SOE}^{*} \mathrm{AD}$ & & & -2.591 & 0.101 & -2.333 & 0.051 & -2.149 & 0.152 \\
\hline $\mathrm{AD}$ & 2.309 & $.000 * *$ & -0.707 & 0.098 & & & 0.18 & 0.69 \\
\hline $\mathrm{CS}$ & -.231 & .067 & -0.018 & 0.814 & & & -0.025 & 0.76 \\
\hline Asset & & & 0.013 & 0.656 & -0.01 & 0.501 & -0.02 & 0.455 \\
\hline Sales & & & 0.556 & $0 * *$ & 0.41 & $0 * *$ & 0.423 & $0^{* *}$ \\
\hline Employee & & & -0.857 & $0^{* *}$ & -1.218 & $0 * *$ & -1.275 & $0^{* *}$ \\
\hline Year1 & & & & & 0.662 & 0.297 & 0.646 & 0.327 \\
\hline Year2 & & & & & 0.701 & 0.254 & 0.713 & 0.269 \\
\hline Year3 & & & & & 1.145 & 0.105 & 1.168 & 0.122 \\
\hline Year4 & & & & & 0.513 & 0.464 & 0.536 & 0.457 \\
\hline Year5 & & & & & 1.403 & 0.07 & 1.404 & 0.077 \\
\hline Year6 & & & & & 1.339 & 0.099 & 1.343 & 0.106 \\
\hline Industry1 & & & & & 7.372 & $0^{* *}$ & 7.628 & $0^{* *}$ \\
\hline Industry2 & & & & & 0.23 & 0.615 & 0.231 & 0.716 \\
\hline Industry3 & & & & & -0.395 & 0.552 & -0.403 & 0.565 \\
\hline Adjusted $\mathrm{R}^{2}$ & \multicolumn{2}{|c|}{0.415} & \multicolumn{2}{|c|}{0.956} & \multicolumn{2}{|c|}{0.973} & \multicolumn{2}{|c|}{0.97} \\
\hline
\end{tabular}

same company from 2000 to 2006 is regarded as different DMUs. An input-oriented constant return to scale (CRS) DEA model was used to compute service operation efficiency.

Table 3 shows that the least efficient company isAsk.com in the year 2002 with a 0.05788 SOE score. Three DMUs, priceline.com in the year 2000, Orbitz Worldwide in the year 2003, and Google in the year 2003 are identified as most efficient with an SOE score of 1 based on input-oriented CRS DEA method.

\subsection{Results of Regression}

Regression considering only three factors including SOE, customer satisfaction, and advertising expenditure is conducted to provide a preliminary result. The regression result shows that only $\mathrm{AD}_{t}$ is positively associated with profit $_{t}(p<0.001)$. Then, SOE impacts on profit are analyzed by the same regression method using control variables including each year and the type of Internet service. Table 4 shows the results of regression taking parallel data into account. As stated, the service operations effi- ciency appears to have a positive impact on the firm's profit. In particular, Model 3, one of four regressions using SOE as an independent variable and profit as the dependent variable, results in a main effect of SOE on profit $(b=29.509, p<0.05)$, suggesting that $\mathrm{SOE}_{t}$ has a significantly positive influence on profit $t_{t}$.

As tested in the previous studies, customer satisfaction can be an indicator to predict the changes in a firm's profit. Many empirical studies have examined this relationship [29,30,31]. In the long term, customer satisfaction is an ultimate goal of the firm and profit can be viewed as a satisfaction input. However, the significant interaction between SOE and customer satisfaction is observed in Model $3(b=-3.44, p<0.05)$ but the sign of effect is not positive. That means there might be a negative moderating effect of customer satisfaction in the service profit chain.

In addition, the research framework posits that advertising expenditure moderates the relationship between SOE and profit. Result shows that the relationship between SOE and profit is moderated by advertising ex- 
penditure but that the moderation effect is unexpectedly negative $(b=-2.333, p<0.1)$. Total sales as a control variable have a significantly positive impact on profit in all models. In contrast, the number of employee is negatively associated with profit. Industry 1 is positively related to profit but other control variables are not.

Next, this paper addresses the relationship between $\mathrm{SOE}$ and subsequent period profit. If the firms maintain a high level of service efficiency, the firms are expected to realize more profits. However, the previous service operations efficiency level does not influence subsequent period profit as seen in Table 5, indicating that there is no lagged effect of service operations efficiency. No interaction effects are found in Model 6 and Model 7. Only similar effects of sales and employees are observed as in Model 3.

\section{Conclusions \& Future Research}

This paper attempts to examine whether or not SPC is applicable to Internet business models. It also investigates the moderating effect of customer satisfaction and advertising expenditures in the service profit chain. The research results are summarized in Table 6. In summary, a firm's service improvement efforts are expected to facilitate positive evaluation of the firm by its customers. Service operations efficiency will create more customer satisfaction, demonstrating if a firm employs a service operations strategy to improve the service quality, more profit can be realized.

Given these results, SOE is one of the best ways to improve a firm's short-term profit, but the lagged impact of SOE on subsequent period profits is not shown by this research. As an example, the news and information category has a relatively high contribution to profit. This can be attributed to unique service delivery characteristics of Internet news services.

The research verifies that service operations efficiency has a relationship with a firm's profit but fails to show a positive moderating effect of customer satisfaction and advertising expenditures in SPC. Unexpectedly, negative moderating effects of those two variables are observed in the regression results. In this sense, if the Internet service providers want to realize more profits, they should place emphasis on service operations efficiency rather than customer satisfaction and advertising spending. As this

Table 5. Regression result $\left(\mathrm{DV}=\right.$ Profit $\left._{t+1}\right)$

\begin{tabular}{|c|c|c|c|c|c|c|}
\hline \multirow[b]{2}{*}{$\mathrm{DV}=$ Profit $_{\mathrm{t}+1}$} & \multicolumn{2}{|c|}{ Model 5} & \multicolumn{2}{|c|}{ Model 6} & \multicolumn{2}{|c|}{ Model 7} \\
\hline & Beta & P-value & Beta & P-value & Beta & P-value \\
\hline (Constant) & 20.037 & .061 & 3.945 & 0.542 & 6.882 & 0.311 \\
\hline SOE & -.328 & .925 & 21.859 & 0.377 & -5.464 & 0.821 \\
\hline $\mathrm{SOE} * \mathrm{CS}$ & & & -2.432 & 0.399 & 0.659 & 0.816 \\
\hline $\mathrm{SOE} * \mathrm{AD}$ & & & -1.423 & 0.425 & 0.141 & 0.934 \\
\hline $\mathrm{AD}$ & 2.339 & $.001 * *$ & -0.908 & 0.081 & -0.179 & 0.752 \\
\hline $\mathrm{CS}$ & -.231 & .097 & -0.049 & 0.566 & -0.086 & 0.325 \\
\hline Asset & & & 0.007 & 0.871 & 0.006 & 0.879 \\
\hline Sales & & & 0.619 & $0 * *$ & 0.316 & $0.01 * *$ \\
\hline Employee & & & -0.883 & $0 * *$ & -1.217 & $0 * *$ \\
\hline Year1 & & & & & 0.231 & 0.736 \\
\hline Year2 & & & & & 0.536 & 0.448 \\
\hline Year3 & & & & & 0.334 & 0.694 \\
\hline Year4 & & & & & 1.129 & 0.17 \\
\hline Year5 & & & & & 1.652 & 0.068 \\
\hline Industry 1 & & & & & 9.809 & 0 \\
\hline Industry2 & & & & & 0.223 & 0.758 \\
\hline Industry3 & & & & & -0.659 & 0.418 \\
\hline Adjusted $\mathrm{R}^{2}$ & \multicolumn{2}{|c|}{0.389} & \multicolumn{2}{|c|}{0.952} & \multicolumn{2}{|c|}{0.971} \\
\hline
\end{tabular}

* significant at 0.05

** significant at 0.01 
moderating effect of advertising expense and customer satisfaction on SPC is not supported, other possible moderators should be identified for future research [32].

Theoretically, this paper contributes to both operations management and marketing scholars by helping focus attention to Internet service operations efficiency, profit, and customer satisfaction. From a practitioner perspective, management can recognize the importance of service operations efficiency in their business practices as a key driver of profitability. One weakness of this paper is the small sample size, which somewhat limits the generalizable nature of the findings. As more data become available, this limitation can be mitigated.

Table 6. Result summary

\begin{tabular}{ccccc} 
IV & DV & Expected & Result & Significant \\
\hline SOE $(\mathrm{t})$ & Profit $(\mathrm{t})$ & + & + & $p<0.1$ \\
$\operatorname{SOE}(\mathrm{t})$ & Profit $(\mathrm{t}+1)$ & + & $+/-$ & n.s. \\
& & & & \\
\hline
\end{tabular}

$\begin{array}{ccccc}\operatorname{SOE}(\mathrm{t}) * \mathrm{CS}(\mathrm{t}) & \text { Profit }(\mathrm{t}) & + & - & p<0.05 \\ & \operatorname{Profit}(\mathrm{t}+1) & + & +- & \text { n.s. }\end{array}$

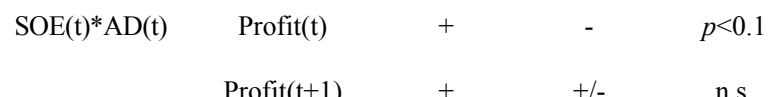

\section{REFERENCES}

[1] L. J. Heskett, T. O. Jones, G. W. Loveman, W. E. Sasser, Jr., and L. Schlesinger, "Putting the service-profit chain to work," Harvard Business Review, 72(2), pp. 164-170, 1994.

[2] G. W. Loveman, "Employee satisfaction, customer loyalty, and financial performance: An empirical examination of the service profit chain in retail banking," Journal of Service Research, 1(1), pp. 18-31, 1998.

[3] A. Soteriou and S. A. Zenios, "Operations, quality, and profitability in the provision of banking services," Management Science, 45(9), pp. 1221-1238, 1999.

[4] W. A. Kamakura, V. Mittal, F. de Rosa, and J. A. Mazzon,
"Assessing the service-profit chain," Marketing Science, 21(3), pp. 294-317, 2002.

[5] M. Pritchard and R. Silvestro, "Applying the service profit chain to analyse retail performance: The case of the managerial strait-jacket?" International Journal of Service Industry Management, 16(4), pp. 337-356, 2005.

[6] D. Bowman and D. Narayandas, "Linking customer management effort to customer profitability in business market," Journal of Marketing Research, 41(4), pp. 433-447, 2004.

[7] R. T. Rust, A. J. Zahorik, and T. L. Keiningham, "Return on Quality (ROQ): Making service quality financially accountable," Journal of Marketing, 59(2), pp. 58-70, 1995.

[8] A. J. Rucci, S. P. Kirn, and R. T. Quinn, "The employ-customer-profit chain at Sears," Harvard Business Review, 76(1), pp. 82-97, 1998.

[9] J. L. Heskett, T. O. Jones, G. W. Loveman, W. E. Sasser, Jr., and L. Schlesinger, "Putting the service-profit chain to work," Harvard Business Review, 86(7/8), pp. 118-129, 2008.

[10] X. M. Luo and C. B. Bhattacharya, "Corporate social responsibility, customer satisfaction, and market value," Journal of Marketing, 70(4), pp. 1-18, 2006.

[11] X. M. Luo and N. Donthu, "Benchmarking advertising efficiency," Journal of Advertising Research, 41(6), pp. 7-18, 2001.

[12] X. M. Luo and N. Donthu, "Assessing advertising media spending inefficiencies in generating sales," Journal of Business Research, 58(1), pp. 28-36, 2005.

[13] X. M. Luo and N. Donthu, "Marketing's credibility: A longitudinal investigation of marketing communication productivity and shareholder value," Journal of Marketing, 70(4), pp. 70-91, 2006.

[14] J. Mahajan, "A data envelopment analytic model for assessing the relative efficiency of the selling function," European Journal of Operational Research, 53(2), pp. 189-205, 1991.

[15] G. E. Fruchter, "The many-player advertising game," Management Science, 45(11), pp. 1609-1611, 1997.

[16] X. M. Luo, "Data envelopment analysis: A management science tool for scientific marketing research," Journal of Marketing Research, 42(3), Book Review, pp. 113-116, 2004.

[17] N. Donthu and B. Yoo, "Retail productivity assessment using data envelopment analysis," Journal of Retailing, 74(1), pp. 89-105, 1998.

[18] W. A. Kamakura, T. Lenartowicz, and B. T. Ratchfrord, "Productivity assessment of multiple retail outlets," Journal of Retailing, 72(4), pp. 333-356, 1996.

[19] J. S. Boles, N. Donthu, and R. Lohtia, "Salesperson evaluation using relative performance efficiency: The application of data envelopment analysis," Journal of Personal Selling \& Sales Management, 15(3), pp. 31-49, 1995. 
[20] B. K. Pilling, N. Donthu, and S. Henson, "Accounting for the impact of territory characteristics on sales performance: Relative efficiency as a measure of salesperson performance," Journal of Personal Selling and Sales Management, 19(2), pp. 35-45, 1999.

[21] G. Reiner and P. Hofmann, "Efficiency analysis of supply chain processes," International Journal of Production Research, 44(23), pp. 5065-5078, 2006.

[22] Y. Chen, L. Liang, and F. Yang, "A DEA game model approach to supply chain efficiency," Annals of Operations Research, 145(1), pp. 5-13, 2006.

[23] A. D. Ross and C. Droge, "An analysis of operations efficiency in large-scale distribution systems," Journal of Operations Management, 21(6), pp. 673-688, 2004.

[24] F. X. Frei and P. T. Harker, "Measuring the efficiency of service delivery processes: An application for retail banking,” Journal of Service Research, 1(4), pp. 300-312, 1999.

[25] D. Lien and Y. Peng, "Measuring the efficiency of search engines: An application of data envelopment analysis," Applied Economics, 31(12), pp. 1581-1587, 1999.

[26] M. Xue and P. T. Harker, "Customer efficiency: Concept and its impact on e-business management," Journal of Service Research, 4(4), pp. 253-267, 2002.

[27] J. Zhu, "Quantitative models for performance evaluations and benchmarking: Data envelopment analysis with spreadsheets and DEA EXCEL solver," Norwell, MA:
Kluwer Academic Publishers Group, 2003.

[28] X. M. Luo and N. Donthu, "Benchmarking advertising efficiency," Journal of Advertising Research, 41(6), pp. 7-18, 2001.

[29] X. M. Luo and C. Homburg, "Neglected outcomes of customer satisfaction," Journal of Marketing, 71(2), pp. 133-149, 2007.

[30] V. Mittal, E. W. Anderson, P. Tadikamalla, and A. Sayrak, "Dual emphasis and the long-term financial impact of customer satisfaction," Marketing Science, 24(4), pp. 544$555,2005$.

[31] B. Cooil, T. L. Keininham, L. Aksoy, and M. Hsu, "A longitudinal analysis of customer satisfaction and share of wallet: Investigating the moderating effect of customer characteristics," Journal of Marketing, 71(1), pp. 67-83, 2007.

[32] X. Y. Liu, "Study on service profit chain: Review and prospect," Services Systems and Services Management, 1(1), pp. 429-434, 2005.

[33] M. J. Farrell, "The measurement of productive efficiency," Journal of the Royal Statistical Society Series A, 120(3), pp. 253-281, 1957.

[34] A. Charnes, W. Cooper, and E. Rhodes, "Measuring the efficiency of decision making units," European Journal of Operational Research, 3(6), pp. 429-444, 1978. 


\section{Appendix. Background and Applications of DEA}

Building on the ideas of Farrell (1957), the seminal work "Measuring the Efficiency of Decision-Making Units" by Charnes, Cooper \& Rhodes (1978) applies linear programming to estimate an empirical production technology frontier for the first time [33, 34]. Since then, there have been a large number of books and journal articles written on DEA or applying DEA to various sets of problems. In addition to comparing efficiency across DMUs within an organization, DEA has been used to compare efficiency across firms. There are several types of DEA methodologies, with the most basic being CCR based on Charnes, Cooper \& Rhoades. However there are also more sophisticated DEA methodologies which address varying returns to scale, either CRS (constant returns to scale) or VRS (variable returns to scale) [27].

Grounded in microeconomic theory, DEA efficiency provides guidelines and benchmarks for both public and private enterprises to achieve maximized desirable ends at minimized costs. DEA measurement has been used to evaluate and compare educational departments (schools, colleges and universities), health care (hospitals, clinics) prisons, agricultural production, banking, armed forces, sports, market research, transportation (highway maintenance), courts, benchmarking, index number construction and many other applications.

In addition, DEA optimizes on each individual observation and provides a ratio score to indicate the relative efficiency performance against the set of Pareto-efficient frontiers. An efficient observation is one for which no other observations, or linear combination of observations in the sample, generate as much as or more outputs given the level of inputs (or consume as much as or less inputs given the level of outputs). DEA is best characterized by the following [16]:

- A focus on individual observations in contrast to populations average

- Production of single aggregate measure for each decision making unit (DMU) in terms of its input factors (independent variables) to produce desired outputs (dependent variables)

- Simultaneous use of multiple outputs and multiple inputs, where each is stated in different units of measurement

- Ability to adjust to exogenous variables

- Ability to incorporate categorical (dummy) variables

- No required specification or knowledge of a priori weights or prices for the inputs or outputs and value free

- No restrictions on the functional form of the production relationship

- Ability to accommodate judgment when desired

- Production of specific estimates for desired changes in inputs and/or outputs for projecting DMUs below the efficient frontier onto the efficient frontier

- Pareto optimal

- A focus on the revealed best-practice frontier rather than on the central tendency properties of frontier

- Satisfaction of strict equity criteria in the relative evaluation of each DMU

- Relationship with performance evaluation and benchmarking 